\title{
Molecular characteristics and taxonomic status of morphologically similar barnacles (Amphibalanus) assessed using the cytochrome c oxidase 1 gene
}

\author{
SRI RIANI", ROMANUS EDY PRABOWO ${ }^{\text {} \psi}$, AGUS NURYANTO ${ }^{\text {}}$, \\ Faculty of Biology, Universitas Jenderal Soedirman. J1. Dr. Soeparno 63, Purwokerto Utara, Banyumas 53122, Central Java, Indonesia. \\ Tel.+62-281-638794, fax.+62-281-631700, `email: sririani92@gmail.com, •vemail: romanus@unsoed.ac.id, vv»email: agus.nuryanto@unsoed.ac.id
}

Manuscript received: 11 November 2020. Revision accepted: 24 February 2021.

\begin{abstract}
Riani S, Prabowo RE, Nuryanto A. 2021. Molecular characteristics and taxonomic status of morphologically similar barnacles (Amphibalanus) assessed using the cytochrome c oxidase 1 gene. Biodiversitas 22: 1456-1466. Amphibalanus variegatus and A. reticulatus have similar external morphology. Morphological similarities can be a severe problem for direct species-level identification. The problem can be overcome through anatomy-based identification and validated through molecular barcoding. Molecular characterization using the cytochrome c oxidase 1 (COI) gene provides a useful tool for precise species identification. This study attempted to assess the molecular characteristics of morphologically similar barnacle (Amphibalanus) specimens collected at five localities in Indonesia to validate their taxonomic status. Forty-five barnacle specimens were collected during the field trips in Lampung, Jakarta, Semarang, Bali, and Lombok. The COI gene was amplified using LCO1490 and HCO2198 primers. The gene was sequenced using bidirectional sequencing at $1^{\text {st }}$ base Asia. The specimens' taxonomic status was determined based on sequence identity, genetic distance, monophyly, nucleotide compositions, and nucleotides in a particular position. Shell shapes-based identification placed barnacle specimens into A. reticulatus. However, anatomical-based identification placed barnacle samples into two different anatomic groups, which was further validated by molecular data that two anatomic groups of Amphibalanus samples have significant differences in their COI gene. Based on the molecular characteristics, 43 samples were identified as A. reticulatus, while the two remaining samples were identified as A. variegatus.
\end{abstract}

Keywords: Amphibalanus, Balanus, genetic distance, identification, species complex

\section{INTRODUCTION}

The barnacles are sessile crustacean and show morphological differences from the other crustaceans (Fertl and Newman 2018). The barnacles have planktonic larvae and sessile adult stages (Maruzzo et al. 2012; Chen et al. 2014; Fertl and Newman 2018). This crustacean is a cosmopolite organism that inhabits a broad range of habitats - ranging from deep-sea ocean to intertidal zones (Jones 2012). Nevertheless, most barnacles live in intertidal and subtidal zones (Fertl and Newman 2018). Thoracica is the most familiar group of barnacles (Newman and Ross 1976; Pérez-Losada et al. 2004). Adult individuals of these barnacles are attached permanently to a wide range of substrates and other living organisms (Fertl and Newman 2018; Power et al. 2010). Within Thoracica, there is an order called Sessilia, which consists of several families, including Balanidae. Balanidae is divided into Balaninae, Amphibalaninae, and Megabalaninae (Pitombo 2004). Nevertheless, Pitriana et al. (2020) was only found two families in Mollucas waters, namely Amphibalaninae and Megabalaninae.

Amphibalanus is a genus of Amphibalaninae. Formerly, Amphibalanus belonged to Balanus. Therefore, it is difficult for the beginner to differentiate between Amphibalanus and Balanus. Henry and McLaughlin (1975) stated that the genera are different in denticles in the labrum and in the color pattern of the parietal and sheath in Amphibalanus. In the period in which Amphibalanus belonged to Balanus, a Balanus amphitrite complex was described (Pitriana et al. 2020). Later, the Balanus amphitrite complex was further identified and divided into three nominal species: Amphibalanus amphitrite (Pitombo 2004; Chen et al. 2014; Shahdadi et al. 2014; Pochai et al. 2017), A. reticulatus (Pitombo 2004; Pochai et al. 2017) and A. variegatus (Pitombo 2004; Horikoshi and Okamoto 2005).

Amphibalanus amphitrite is characterized by conical to round shells, while Amphibalanus reticulatus has a conical or cylindrical shell, and Amphibalanus variegatus is characterized by steeply conical shells or tubules in crowded populations (Pitriana et al. 2020). The similarities in general morphology of these three species might cause misidentification, especially for beginner taxonomists. According to Henry and McLaughlin (1975), Amphibalanus reticulatus and A. variegatus previously belonged to the Balanus amphitrite complex. Therefore, it is not easy to differentiate them solely based on their morphology. Chen et al. (2014) and Pitriana et al. (2020) further stated that the three species of the Balanus amphitrite complex could be differentiated through anatomical analysis of their shell, tergum, cirri, and the color patterns on their shells. The identification of newly collected Balanus amphitrite complexes is becoming more challenging because they have overlapping geographic 
distributions. Amphibalanus amphitrite is widely distributed worldwide from tropical to subtropical regions (Henry and McLaughlin 1975; Chen et al. 2014). At the same time, A. reticulatus is an indigenous species in the Indo-Pacific (Utinomi 1967; Henry and McLaughlin 1975; Newman and Ross 1976; Puspasari 2001; Carlton et al. 2011), including the Indonesian Archipelago. Although $A$. variegatus has a narrower geographic distribution, Indonesia still belongs to its geographic range, the Indowest Pacific region (Newman and Ross 1976; Puspasari 2001; Henry and McLaughlin 1975; Jones and Hosie 2016).

Morphological constraints faced by beginner barnacle taxonomists can be solved using shell compartments and soft body parts (Chen et al. 2014; Pitriana et al. 2020). It could be further validated using molecular characteristics for species determination (Frankham 2003). Cytochrome c oxidase subunit 1 (COI) has become a standard marker in animal characterization during species-level identification (Riehl et al. 2014; Raupach and Radulovici 2015; Karanovic 2015). The cytochrome c oxidase 1 gene has a highly variable fragment that is decisive for species differentiation of morphologically identical species (von der Heyden et al. 2014), such as members of the $B$. amphitrite complex (Chen et al. 2014). The taxonomic status of the samples can be determined based on sequence identity (Nuryanto et al. 2017; Bhagawati et al. 2020). Other parameters include genetic distance and monophyly of the specimen to the conspecific references (Kusbiyanto et al. 2020, Nuryanto et al. 2018). Variable genetic distances between and among species or within and among families and orders have been reported (Pereira et al. 2013).

Previous studies have proven that the COI gene is a reliable marker for species-level identification of crustaceans (da Silva et al. 2011; Jeffery et al. 2011), including species complexes (Weis et al. 2014). Other studies have also proven that the COI gene is a powerful marker to separate identical morphological species (Camacho et al. 2011; Bilgin et al. 2015; Bekker et al. 2016). Moreover, the COI gene was also reported as a reliable marker for species-level identification of specimens with limited morphological characteristics, such as fish and crustacean larvae (Tang et al. 2010; Ko et al. 2013, Pereira et al. 2013; Thirumaraiselvi et al. 2015; Palero et al. 2016; Palecanda et al. 2020). In barnacles, the COI gene was also reported as a reliable molecular marker for species identification of barnacle specimens (Pitriana et al. 2020). However, Pitriana et al. (2020) only focused on barnacle specimens from Maluku. No study has been performed on the characterization of morphologically similar barnacle specimens collected from different localities in Indonesia.

This study aimed to assess the molecular characteristics of morphologically similar barnacle (Amphibalanus) specimens collected at five localities in Indonesia to validate their taxonomic status. The use of the COI gene on morphologically identical barnacle specimens could validate those barnacles' taxonomic status inferred from morphological identification. A precise taxonomic status is essential for further studies of barnacles, such as studies about the connectivity among barnacle populations across the Indonesian Archipelago. The data are vital as a scientific basis for barnacle species and ecosystem management in Indonesia.

\section{MATERIALS AND METHODS}

\section{Sampling sites and laboratory examination}

Barnacle samples were collected at five localities in Indonesia, spanning Lampung, Jakarta, Semarang, Bali, and Lombok (Figure 1). The locations were selected by considering current changes throughout the western and eastern monsoon seasons in the Java Sea to the Bali and Lombok Straits. The ecological characteristics of all the sampling sites were similar, i.e. salinity ranged from 22 to $25 \%, \mathrm{pH}$ ranged between 6.8 and 7.5, and all the sites were bays. Barnacle samples were collected during field trips in July and August 2020.

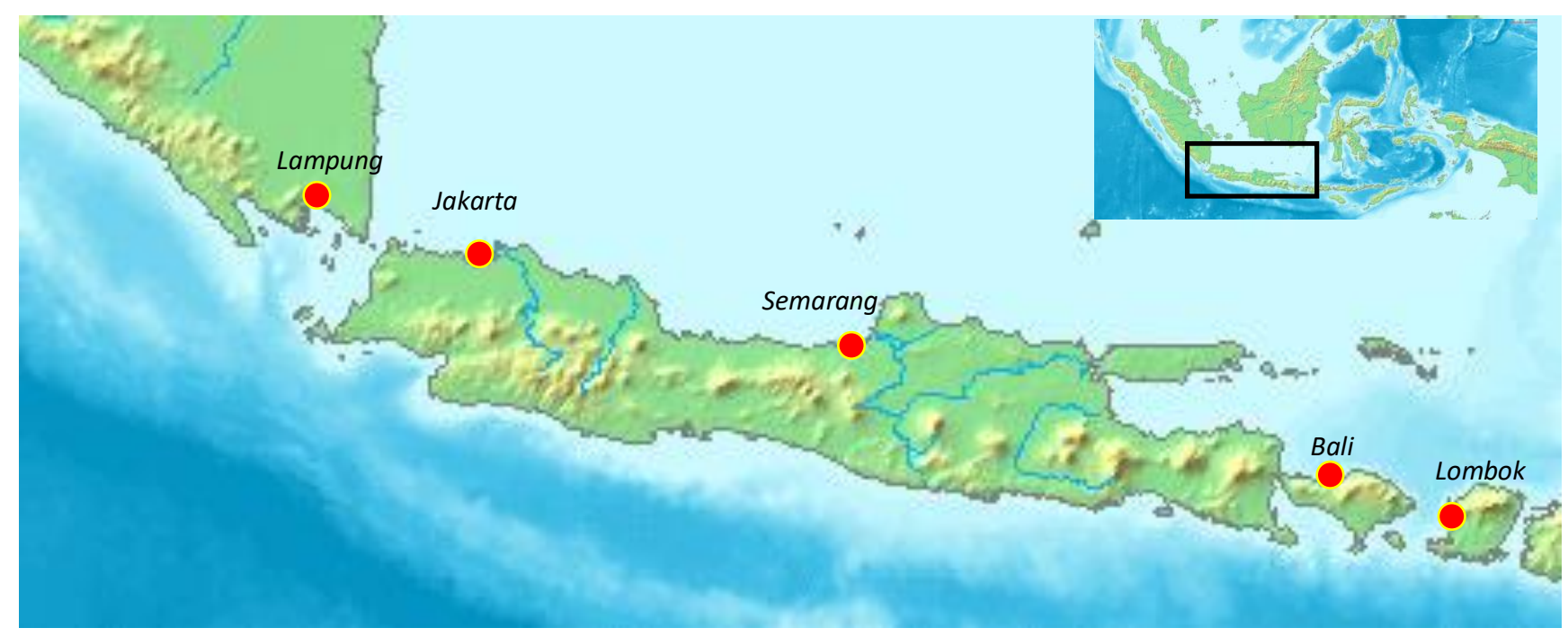

Figure 1. Indonesian archipelagos and sampling sites 


\section{Sample collection and morphospecies identification}

Barnacle samples were collected manually using a chisel and hammer. That sampling technique was applied because barnacles are firmly attached to the substrates. Fresh individuals were directly identified based on shell shape by comparison with previous publications by Puspasari (2001) and Chen et al. (2014). Afterward, barnacle specimens were preserved in $96 \%$ absolute ethanol. Preliminary identification was roughly performed based on shell shape. The purpose of this step was to group identical samples into single morphospecies, which would then need further validation using molecular characteristics.

\section{DNA extraction and COI marker amplification}

Total genomic DNA was extracted from soft body parts of the barnacle samples using Chelex ${ }^{\circledR} 100$ (Walsh et al. 2013). A fragment of the cytochrome c oxidase 1 gene was multiplied using polymerase chain reaction (PCR). The amplification used My HS ready mix (Bioline, Meridian Bioscience) utilizing the forward primer LCO1490, 5'GGTCAACAAATCATAAAGATATTGG-3', and the reverse primer HC02198, 5'-TAAACTTCAGGGTGACC AAAAAATCA-3' (Folmer et al. 1994). A thermal cycler was run under the following conditions: initial denaturation at $95^{\circ} \mathrm{C}$ for 3 minutes, five initial cycles consisting of denaturation at $95^{\circ} \mathrm{C}$ for 30 seconds, 60 seconds of annealing at $48^{\circ} \mathrm{C}$, and extension for 60 seconds at $72^{\circ} \mathrm{C}$. The actual amplification process was conducted for 35 cycles with denaturation at $95^{\circ} \mathrm{C}$ for 30 seconds, annealing at $51^{\circ} \mathrm{C}$ for 45 seconds, and extension for one minute at $72^{\circ} \mathrm{C}$. The final extension was performed for nine minutes at $72^{\circ} \mathrm{C}$, followed by a hold stage at $8^{\circ} \mathrm{C}$ for five minutes. Extracted DNA and amplification products were visualized in a SyBr-stained agarose gel over a UV light transilluminator.

\section{Data analysis}

Forward and reverse sequences of all samples were assembled using Bioedit (Hall 2005) to obtain a complete fragment. The complete sequences were translated to amino acid sequences using ORF finder online software (https://www.ncbi.nlm.nih.gov/orffinder/) to ensure that functional fragments were obtained. All sequences were checked for their identity to conspecific sequences in GenBank using the basic local alignment search tool (BLAST) technique. Multiple sequence alignment was performed using ClustalW (Thompson et al. 1994) in Bioedit (Hall 2005), and sequences were checked manually to avoid unnecessary sites or gaps. All sequences have been deposited in GenBank with accession numbers MW196394 to MW196438.

Nucleotide content and the number of polymorphic sites of each species were calculated using Arlequin 3.5. (Excoffier and Lischer 2010). Monophyly of barnacle samples and their conspecific references was obtained through phylogenetic analysis. The phylogenetic tree was reconstructed using neighbor-joining $(\mathrm{NJ})$ and maximum likelihood algorithms and the Kimura 2-parameter (K2P) substitution model in MEGAX (Kumar et al. 2018). The reliability of the tree topology was obtained from outgroup comparisons using other barnacle species harvested from GenBank and 1000 bootstrap values. The outgroup specimens were Amphibalanus amphitrite KU204305, Amphibalanus improvisus MG935146, Amphibalanus rhizophorae JQ035511, Amphibalanus eburneus MK240319, Amphibalanus subalbidus MK308125, Amphibalanus zhujiangensis MK995341, Amphibalanus cirratus MG450353, Balanus glandula MG319462, Semibalanus balanoides HQ987373, and Haptosquilla hamifera KM074037. These distantly related specimens were used to ensure that all barnacle species formed a monophyletic group.

\section{RESULTS AND DISCUSSION}

\section{Morphospecies concept}

Forty-five barnacle samples were obtained during field trips in Lampung, Jakarta, Semarang, Bali, and Lombok. Shell shape-based identification of fresh samples placed 45 barnacle specimens into a single morphospecies, namely, Amphibalanus reticulatus. The sample placement into a single morphospecies is reasonable because species definition was solely based on morphological similarity. Claridge et al. (1997) clearly stated that species status is only determined based on morphological similarity in the morphological species concept. The second argument is in the previous classification that Amphibalanus belonged to Balanus. Previously, all Amphibalanus species were placed into a single species, namely, the Balanus amphitrite species complex. The placement was because all Amphibalanus species have remarkably similar external morphologies, especially in their shell shapes (Pitombo 2004). Therefore, it was reasonable that skimming identification of newly collected samples placed all samples into single species.

Anatomical assessment based on their shells compartments and soft body parts placed the samples into two distinct anatomic groups. The first groups consisted of 43 barnacle individuals collected from Lampung, Semarang, Bali, and Lombok. The second group only consisted of two barnacle individuals from Jakarta. The first anatomic group was identified as A. reticulatus, while the second group was anatomically identified as $A$. variegatus. The difference in results between shell shape and anatomy-based identification is reasonable because anatomic characters, such as shell compartments, labrum shapes, and erect hook on the posterior distal of cirri III, are diagnostic characters species-level identification of barnacles. Previous studies had proved that barnacle species could be identified based on shell compartments and soft body parts of the specimens (Hanry and McLaughlin 1975; Puspasari 2001; Pitriana et al. 2020). 
Table 1. Nucleotide differences between two groups of morphologically similar barnacles

\begin{tabular}{|c|c|c|c|c|c|c|c|c|c|c|c|c|c|c|}
\hline \multirow[b]{2}{*}{ Group } & \multicolumn{14}{|c|}{ Nucleotide position } \\
\hline & 12 & 14 & 23 & 32 & 74 & 77 & 83 & 95 & 116 & 125 & 143 & 146 & 162 & 164 \\
\hline Group 1 & $\mathrm{C}$ & $\mathrm{T}$ & A & $\mathrm{C}$ & $\mathrm{C}$ & $\mathrm{C}$ & $\mathrm{T}$ & $\mathrm{T}$ & $\mathrm{C}$ & $\mathrm{A}$ & $\mathrm{G}$ & A & $\mathrm{T}$ & A \\
\hline \multirow[t]{2}{*}{ Group 2} & $\mathrm{~T}$ & A & $\mathrm{T}$ & $\mathrm{T}$ & $\mathrm{T}$ & $\mathrm{T}$ & A & A & $\mathrm{T}$ & $\mathrm{T}$ & $\mathrm{T}$ & $\mathrm{T}$ & $\mathrm{C}$ & $\mathrm{T}$ \\
\hline & 167 & 182 & 185 & 191 & 194 & 204 & 206 & 212 & 228 & 230 & 239 & 263 & 264 & 266 \\
\hline Group 1 & $\mathrm{~T}$ & $\mathrm{~T}$ & $\mathrm{~T}$ & $\mathrm{~T}$ & $\mathrm{C}$ & $\mathrm{T}$ & A & $\mathrm{T}$ & $\mathrm{C}$ & $\mathrm{T}$ & $\mathrm{T}$ & $\mathrm{C}$ & $\mathrm{C}$ & $\mathrm{T}$ \\
\hline \multirow[t]{2}{*}{ Group 2} & A & $\mathrm{C}$ & A & A & $\mathrm{T}$ & $\mathrm{C}$ & $\mathrm{T}$ & $\mathrm{C}$ & $\mathrm{T}$ & A & $\mathrm{C}$ & $\mathrm{T}$ & $\mathrm{T}$ & A \\
\hline & 299 & 314 & 317 & 362 & 363 & 365 & 374 & 383 & 398 & 401 & 413 & 416 & 419 & 434 \\
\hline Group 1 & $\mathrm{~T}$ & G/A & $\mathrm{T} / \mathrm{C}$ & A & $\mathrm{C}$ & $\mathrm{T}$ & $\mathrm{T}$ & $\mathrm{T}$ & A & $\mathrm{C}$ & $\mathrm{T}$ & A & $\mathrm{T} / \mathrm{C}$ & A \\
\hline \multirow[t]{2}{*}{ Group 2} & G & $\mathrm{T}$ & A & $\mathrm{T}$ & $\mathrm{T}$ & A & A & $\mathrm{C}$ & $\mathrm{T}$ & $\mathrm{T}$ & A & $\mathrm{T}$ & A & $\mathrm{T}$ \\
\hline & 440 & 441 & 458 & 470 & 479 & 488 & 504 & 506 & 524 & 540 & 542 & 545 & 548 & 581 \\
\hline Group 1 & A & $\mathrm{C}$ & $\mathrm{T}$ & $\mathrm{T}$ & $\mathrm{T}$ & $\mathrm{A} / \mathrm{C}$ & $\mathrm{C}$ & $\mathrm{T}$ & $\mathrm{C} / \mathrm{T}$ & $\mathrm{T}$ & A & A & $\mathrm{T}$ & $\mathrm{T}$ \\
\hline Group 2 & $\mathrm{C}$ & $\mathrm{T}$ & A & A & A & $\mathrm{T}$ & $\mathrm{T}$ & A & A & $\mathrm{C}$ & $\mathrm{C}$ & $\mathrm{T}$ & A & A \\
\hline
\end{tabular}

\section{Molecular characteristics}

To ensure that the barnacle samples utilized were precisely identified to the correct taxonomic status, all samples were subjected to molecular characterization using the COI gene. Two molecular characteristics were assessed, i.e., nucleotide differences at a particular position and nucleotide composition.

\section{Nucleotide differences}

Pairwise comparisons of all barnacle samples' nucleotide sequences proved that the samples could be divided into two distinct genetic groups. The first group consisted of 43 barnacle samples collected at Lampung, Semarang, Bali, and Lombok. The first group shows fairly high nucleotides variation. The 43 individuals of first group were differentiated by 36 nucleotides. The second group consisted of only two barnacle individuals collected in Jakarta. The two individuals of the second group differ only in 3 nucleotides. Meanwhile, the first group was distinguished from the second group by the difference in nucleotides at 56 positions (Table 1). The nucleotide differences between these two morphologically similar samples are presented in Table 1. Those high nucleotide differences indicate that both barnacle groups are genetically different, which might suggest that they belong to different species. According to Elvyra et al. (2020), nucleotide differences among samples might indicate that the samples belong to different species. Similar phenomenon was also reported in fish (Malakar et al. 2013)

\section{Nucleotide composition}

Further analysis was performed to compare the nucleotide composition of previously genetically different groups, as shown in their nucleotide differences. Mathematical calculations proved that both groups had different nucleotide compositions. The nucleotide compositions of both genetic groups are presented in Table 2.

Table 2 shows that both species have different percentages of their nucleotides. The difference in nucleotide composition could indicate that the morphospecies groups belong to different species. According to Afreixo et al. (2009), a distinct nucleotide composition pattern might suggest a species' indication and characteristics. A different nucleotide was also reported in fish (Malakar et al. 2013; Elvyra et al.2020). As also shown in Table 2, guanine $(\mathrm{G})$ is present in the lowest percentage.

\section{Genetic species concept}

The genetic species concept can be applied if closely related species show a highly similar morphology. In such a case, species identification solely relying on morphological characteristics might lead to misidentification (Pitriana et al. 2020). The genetic species concept states that high similarity in genetic constituents of two or more individuals can be referred to as belonging to a single species, as summarized by Claridge et al. (1997). In technical terms, genetic similarity can be assessed through sequence identity, genetic distances, and individual monophyly (Bhagawati et al. 2020; Kusbiyanto et al. 2020).

\section{BLAST parameters}

Sequence identity checks using the BLAST (Basic Local Alignment Search Tool) technique proved that 43 out of the 45 morphospecies had high identity values to the sequences of $A$. reticulatus available in GenBank. The identity values ranged from $98.11 \%$ to $100 \%$, the query cover ranged from $99 \%$ to $100 \%$, and the expected value was 0 . However, the two morphospecies had sequence identity values ranging from $99.53 \%$ to $99.84 \%$, a query cover of $99 \%$, and an expected value of 0 for A. variegatus in GenBank (MK995342, MK995343, and MK995345). Detailed data on the BLAST results are presented in Table 3.

Table 2. Nucleotide compositions of two groups of morphologically similar barnacles

\begin{tabular}{ccccc}
\hline \multirow{2}{*}{$\begin{array}{c}\text { Morphospecies } \\
\text { group }\end{array}$} & $\mathbf{C}$ & $\mathbf{T}$ & $\mathbf{A}$ & $\mathbf{G}$ \\
\cline { 2 - 5 } Nucleotide (\%) \\
\hline Group 1 & 17.42 & 37.70 & 29.17 & 15.71 \\
Group 2 & 16.27 & 38.12 & 30.46 & 15.15 \\
\hline
\end{tabular}


Table 3. BLAST analysis results to conspecific sequences available in GenBank

\begin{tabular}{|c|c|c|c|c|c|}
\hline Sample & Query cover (\%) & E-Value & Identity (\%) & Conspecific references & Accession number \\
\hline \multirow[t]{2}{*}{ B1_01 } & 100 & 0 & 99.84 & Amphibalanus reticulatus & KU204370 \\
\hline & 100 & 0 & 99.69 & & KU204350 \\
\hline \multirow[t]{2}{*}{ B1_02 } & 100 & 0 & 99.84 & Amphibalanus reticulatus & KU204350 \\
\hline & 99 & 0 & 100.00 & Amphibalanus sp. & MK995352 \\
\hline \multirow[t]{2}{*}{ B1_03 } & 100 & 0 & 98.28 & Amphibalanus reticulatus & KU204256 \\
\hline & 100 & 0 & 98.13 & Amphibalanus reticulatus & KU204346 \\
\hline \multirow[t]{2}{*}{ B1_04 } & 100 & 0 & 99.84 & Amphibalanus reticulatus & KU204370 \\
\hline & 100 & 0 & 99.69 & & KU204350 \\
\hline \multirow[t]{2}{*}{ B1_05 } & 100 & 0 & 99.38 & Amphibalanus reticulatus & KU204320 \\
\hline & 100 & 0 & 99.22 & Amphibalanus reticulatus & KU204369 \\
\hline \multirow[t]{2}{*}{ B1_06 } & 100 & 0 & 100 & Amphibalanus sp. & MK995349 \\
\hline & 100 & 0 & 100 & Amphibalanus reticulatus & KU204350 \\
\hline \multirow[t]{2}{*}{ B1_07 } & 100 & 0 & 100 & Amphibalanus reticulatus & KU204350 \\
\hline & 100 & 0 & 99.84 & Amphibalanus reticulatus & KU204370 \\
\hline \multirow[t]{2}{*}{ B1_08 } & 100 & 0 & 98.14 & Amphibalanus reticulatus & KU204256 \\
\hline & 99 & 0 & 98.13 & Amphibalanus reticulatus & KU204370 \\
\hline \multirow{2}{*}{ B1_10 } & 100 & 0 & 98.11 & Amphibalanus reticulatus & KU204370 \\
\hline & 100 & 0 & 98.11 & Amphibalanus reticulatus & KU204256 \\
\hline \multirow[t]{2}{*}{ B1_11 } & 100 & 0 & 98.42 & Amphibalanus reticulatus & KU204256 \\
\hline & 100 & 0 & 98.26 & Amphibalanus reticulatus & KU204346 \\
\hline \multirow{2}{*}{ Bl_12 } & 100 & 0 & 99.84 & Amphibalanus reticulatus & KU204350 \\
\hline & 100 & 0 & 99.69 & Amphibalanus reticulatus & KU204370 \\
\hline \multirow[t]{2}{*}{ Bl_13 } & 99 & 0 & 98.13 & Amphibalanus reticulatus & KU204256 \\
\hline & 100 & 0 & 97.83 & Amphibalanus reticulatus & KU204370 \\
\hline \multirow[t]{2}{*}{ Bl_15 } & 100 & 0 & 99.69 & Amphibalanus reticulatus & KU204370 \\
\hline & 100 & 0 & 99.53 & Amphibalanus sp. & MK995349 \\
\hline Lb_01 & 99 & 0 & 98.13 & Amphibalanus reticulatus & KU204256 \\
\hline & 99 & 0 & 97.97 & Amphibalanus reticulatus & KU204346 \\
\hline Lb_02 & 100 & 0 & 99.69 & Amphibalanus reticulatus & KU204370 \\
\hline & 100 & 0 & 99.53 & Amphibalanus reticulatus & KU204350 \\
\hline Lb_03 & 100 & 0 & 99.84 & Amphibalanus reticulatus & KU204320 \\
\hline & 100 & 0 & 99.68 & Amphibalanus reticulatus & KU204369 \\
\hline Lb_04 & 100 & & 99.38 & Amphibalanus reticulatus & KU204346 \\
\hline & 100 & 0 & 99.38 & Amphibalanus reticulatus & KU204256 \\
\hline Lb_05 & 100 & 0 & 99.53 & Amphibalanus reticulatus & KU204346 \\
\hline & 100 & 0 & 99.53 & Amphibalanus reticulatus & KU204256 \\
\hline Lb_06 & 100 & 0 & 100 & Amphibalanus reticulatus & KU204370 \\
\hline & 100 & 0 & 99.84 & Amphibalanus reticulatus & KU204350 \\
\hline Lb_08 & 100 & 0 & 100 & Amphibalanus reticulatus & KU204370 \\
\hline & 100 & 0 & 99.84 & Amphibalanus reticulatus & KU204350 \\
\hline Lb_09 & 100 & 0 & 100 & Amphibalanus reticulatus & KU204350 \\
\hline & 100 & 0 & 99.84 & Amphibalanus reticulatus & KU204370 \\
\hline Lb_12 & 100 & 0 & 100 & Amphibalanus reticulatus & KU204370 \\
\hline & 100 & 0 & 99.84 & Amphibalanus reticulatus & KU204350 \\
\hline Lb_15 & 99 & 0 & 100 & Amphibalanus sp. & MK995352 \\
\hline & 99 & 0 & 100 & Amphibalanus sp. & MK995351 \\
\hline & 99 & 0 & 99.83 & Amphibalanus reticulatus & KU204350 \\
\hline Lp_01 & 100 & 0 & 100 & Amphibalanus reticulatus & KU204350 \\
\hline & 100 & 0 & 99.84 & Amphibalanus reticulatus & KU204370 \\
\hline Lp_02 & 100 & 0 & 100 & Amphibalanus reticulatus & KU204350 \\
\hline & 100 & 0 & 99.84 & Amphibalanus reticulatus & KU204370 \\
\hline Lp_04 & 100 & 0 & 99.84 & Amphibalanus reticulatus & KU204350 \\
\hline & 99 & 0 & 100 & Amphibalanus sp. & MK995352 \\
\hline Lp_06 & 100 & 0 & 99.69 & Amphibalanus reticulatus & KU204350 \\
\hline & 100 & 0 & 99.53 & Amphibalanus reticulatus & KU204370 \\
\hline Lp_07 & 100 & 0 & 100 & Amphibalanus reticulatus & KU204350 \\
\hline & 100 & 0 & 99.84 & Amphibalanus reticulatus & KU204370 \\
\hline Lp_09 & 100 & 0 & 100 & Amphibalanus reticulatus & KU204350 \\
\hline & 100 & 0 & 99.84 & Amphibalanus reticulatus & KU204370 \\
\hline Lp_10 & 100 & 0 & 100 & Amphibalanus reticulatus & KU204350 \\
\hline & 100 & 0 & 99.84 & Amphibalanus reticulatus & KU204370 \\
\hline Lp_12 & 100 & 0 & 100 & Amphibalanus sp. & MK995349 \\
\hline & 100 & 0 & 100 & Amphibalanus reticulatus & KU204350 \\
\hline Lp_15 & 100 & 0 & 100 & Amphibalanus reticulatus & KU204350 \\
\hline & 100 & 0 & 99.84 & Amphibalanus reticulatus & KU204370 \\
\hline
\end{tabular}




\begin{tabular}{|c|c|c|c|c|c|}
\hline \multirow[t]{2}{*}{ Sr_01 } & 100 & 0 & 99.84 & Amphibalanus reticulatus & KU204256 \\
\hline & 100 & 0 & 99.53 & Amphibalanus reticulatus & KU204346 \\
\hline \multirow[t]{2}{*}{ Sr_02 } & 100 & 0 & 99.84 & Amphibalanus reticulatus & KU204350 \\
\hline & 99 & 0 & 100 & Amphibalanus sp. & MK995352 \\
\hline \multirow[t]{2}{*}{ Sr_03 } & 99 & 0 & 100 & Amphibalanus reticulatus & KU204350 \\
\hline & 99 & 0 & 100 & Amphibalanus reticulatus & KU204261 \\
\hline \multirow[t]{2}{*}{ Sr_04 } & 100 & 0 & 99.69 & Amphibalanus reticulatus & KU204350 \\
\hline & 99 & 0 & 99.84 & Amphibalanus sp. & MK995352 \\
\hline \multirow[t]{2}{*}{ Sr_05 } & 100 & 0 & 100 & Amphibalanus reticulatus & KU204350 \\
\hline & 100 & 0 & 99.84 & Amphibalanus reticulatus & KU204370 \\
\hline \multirow[t]{2}{*}{ Sr_06 } & 100 & 0 & 99.84 & Amphibalanus reticulatus & KU204350 \\
\hline & 99 & 0 & 100 & Amphibalanus sp. & MK995352 \\
\hline \multirow[t]{2}{*}{ Sr_07 } & 100 & 0 & 99.84 & Amphibalanus sp. & MK995349 \\
\hline & 100 & 0 & 99.84 & Amphibalanus reticulatus & KU204350 \\
\hline \multirow[t]{2}{*}{ Sr_09 } & 100 & 0 & 100. & Amphibalanus reticulatus & KU204370 \\
\hline & 100 & 0 & 99.84 & Amphibalanus reticulatus & KU204350 \\
\hline \multirow[t]{2}{*}{ Sr_10 } & 100 & 0 & 99.84 & Amphibalanus reticulatus & KU204350 \\
\hline & 99 & 0 & 100 & Amphibalanus sp. & MK995352 \\
\hline \multirow[t]{2}{*}{ Sr_13 } & 100 & 0 & 100 & Amphibalanus reticulatus & KU204370 \\
\hline & 100 & 0 & 99.84 & Amphibalanus reticulatus & KU204350 \\
\hline \multirow[t]{2}{*}{ Sr_15 } & 100 & 0 & 99.84 & Amphibalanus reticulatus & KU204350 \\
\hline & 99 & 0 & 100 & Amphibalanus sp. & MK995352 \\
\hline \multirow[t]{2}{*}{ Jt_02 } & 99 & 0 & 99.69 & Amphibalanus variegatus & MK995345 \\
\hline & 99 & 0 & 99.53 & Amphibalanus variegatus & MK995343 \\
\hline \multirow[t]{2}{*}{ Jt_03 } & 99 & 0 & 99.84 & Amphibalanus variegatus & MK995343 \\
\hline & 99 & 0 & 99.84 & Amphibalanus variegatus & MK995342 \\
\hline
\end{tabular}

Table 3 shows that 43 morphospecies have a high sequence identity to $A$. reticulatus deposited in GenBank with a high query cover and an expected value of 0 . Based on the BLAST parameters, 43 morphospecies (Bl_01 to $\left.\mathrm{Sr} \_15\right)$ were genetically identified as A. reticulatus. The two remaining morphospecies (Jt_02 and Jt_03) have high BLAST identity to A. variegatus available in GenBank. According to the BLAST parameters in Table 3, both morphospecies were genetically identified as A. variegatus. The morphospecies was placed into A. reticulatus and $A$. variegatus because the identity values were higher than 97\% standard values, as used in BOLD systems for species identity (Ratnasingham 2016; Ratnasingham and Hebert 2007). High genetic homology among barnacle samples and their reference species was also reported (Pitriana et al. 2020). Similar phenomena were also reported in other crustaceans (Bilgin et al. 2015; Bhagawati et al. 2020; Kusbiyanto et al. 2020). Therefore, it can be stated that high genetic homology among individuals within species is a common phenomenon over a wide range (Nuryanto et al. 2017; Ko et al. 2013).

Of course, there are some exceptions: individuals from a single species might have low sequence identities (Karanovic et al. 2015; Lin et al. 2015). The phenomena are common in natural populations. By studying a wide range of taxa, we realized that different groups of animals might show distinct genetic homology within species. da Silva et al. (2011) and Bucklin et al. (2010) proved that different groups of animal species showed highly variable genetic homology and differences among intraspecific individuals. All these previous studies strengthen our decision that genetically distinct barnacle morphospecies can be referred to as two genetic species.

\section{Genetic distances}

Genetic distance indicates genetic differences among species or populations within species. Kimura 2-parameter (K2P) genetic distance analysis showed that 43 morphospecies (Group 1) had low genetic distance to $A$. reticulatus in GenBank. The genetic distances ranged between $0.000 \%$ and $2.647 \%$. Simultaneously, genetic distances among two morphospecies (Group 2) samples had low genetic distances to A. variegatus in GenBank. The values ranged from $0.000 \%$ to $0.346 \%$. The genetic distance between morphospecies Group 1 and morphospecies Group 2 samples ranged from $12.964 \%$ to $14.438 \%$. Genetic distances among all samples to the conspecific sequences are presented in Table 4.

Table 4 clearly shows that barnacle samples from Lampung, Semarang, Bali, and Lombok (Group 1) have a low genetic distance to $A$. reticulatus. Simultaneously, barnacle samples from Jakarta (Group 2) had low genetic distances to $A$. variegatus. The data on genetic distance between sample and reference species, as shown in Table 4, have provided additional information and validated BLAST analysis. Therefore, morphologically identical barnacle samples collected at five localities consisted of two different species, i.e., A. reticulatus and A. variegatus. The decision was made because the genetic distances were less than 3\% compared with their reference species. This conclusion was strengthened by high genetic distances between samples from four populations (Group 1) and from Jakarta (Group 2), which was over 3\% (12.964\% to $14.438 \%$ ), indicating that both groups belonged to different species. Low within-species genetic distances have been reported in several studies. For example, Camacho et al. (2011) reported genetic distances within Vejdovskybathynella edelweiss species that ranged from $1.5 \%$ to $2 \%$. Similar values were also reported in a wide 
range of animal phyla (Camacho, 2011; Hubert et al. 2012; Nuryanto et al. 2017; Nuryanto et al. 2019; Bhagawati et al. 2020). Therefore, there is no doubt that barnacle samples from Lampung, Semarang, Bali, and Lombok belong to $A$. reticulatus. In contrast, barnacle samples from Jakarta belong to A. variegtaus, although they have similar morphology.

The cutoff value of $3 \%$ genetic distance was utilized during species determination. This is because that value is the standard value used in BOLD systems for species identity (Ratnasingham and Hebert 2007). Moreover, genetic distances among individuals within species are highly variable depending on the animal groups. For example, intraspecific genetic distance within insects reached 21.1\% (Lin et al. 2015), while Aguilar et al. (2017) reported that the highest genetic distance in Bracnchinecta lindahli (Crustacea: Anostraca) was 7.4\%. Moreover, da Silva et al. (2011), Havermans et al. (2011), and Bilgin et al. (2015) also reported high variability in intraspecific genetic distance among crustacean species. Karanovic et al. (2015) reported that genetic distance within ostracods (Crustacea) reached $8.6 \%$. Therefore, the use of $3.0 \%$ genetic distance for species cutoffs within this study is reasonable. The value is below the $5 \%$ cutoff value used by Candek and Kuntner (2015) in insects and inside the range of $4 \%$ to $5 \%$ used by Lin et al. (2015).

\section{Phylogenetic analysis}

The phylogenetic tree showed that barnacles species formed a monophyletic clade compared with the outgroup species (Nodus N; Figure 2). Figure 2 reveals that each sample was monophyletic to their conspecific. Forty-three samples from Lampung, Semarang, Bali, and Lombok formed a single clade with $A$. reticulatus (Clade A, Figure 2). Two samples from Jakarta formed another clade with $A$. variegatus (Clade B; Figure 2). The samples' monophyly to their reference species was supported by an almost perfect bootstrap value of 99 . This value indicated that 990 out of 1000 trees that were reconstructed during the analysis had similar branching patterns for the monophyly of barnacle samples with their reference species.

Table 4. Genetic distances among samples to conspecific species

\begin{tabular}{|c|c|c|c|}
\hline Sample & Conspecific sequences & $\begin{array}{c}\text { Accession } \\
\text { number }\end{array}$ & $\begin{array}{c}\text { Genetic } \\
\text { distance }(\%)\end{array}$ \\
\hline \multirow[t]{2}{*}{ B1_01 } & Amphibalanus reticulatus & KU204370 & 0.173 \\
\hline & & KU204350 & 0.346 \\
\hline \multirow[t]{2}{*}{ B1_02 } & Amphibalanus reticulatus & KU204350 & 0.173 \\
\hline & Amphibalanus sp. & MK995352 & 0.346 \\
\hline \multirow[t]{2}{*}{ B1_03 } & Amphibalanus reticulatus & KU204256 & 1.925 \\
\hline & Amphibalanus reticulatus & KU204346 & 2.104 \\
\hline \multirow[t]{2}{*}{ B1_04 } & Amphibalanus reticulatus & KU204370 & 0.173 \\
\hline & & KU204350 & 0.346 \\
\hline \multirow[t]{2}{*}{ B1_05 } & Amphibalanus reticulatus & KU204320 & 0.346 \\
\hline & Amphibalanus reticulatus & KU204369 & 0.520 \\
\hline \multirow[t]{2}{*}{ B1_06 } & Amphibalanus sp. & MK995349 & 2.647 \\
\hline & Amphibalanus reticulatus & KU204350 & 0.000 \\
\hline \multirow[t]{2}{*}{ B1_07 } & Amphibalanus reticulatus & KU204350 & 0.000 \\
\hline & Amphibalanus reticulatus & KU204370 & 0.173 \\
\hline \multirow[t]{2}{*}{ B1_08 } & Amphibalanus reticulatus & KU204256 & 2.104 \\
\hline & Amphibalanus reticulatus & KU204370 & 1.928 \\
\hline \multirow[t]{2}{*}{ Bl_10 } & Amphibalanus reticulatus & KU204370 & 2.106 \\
\hline & Amphibalanus reticulatus & KU204256 & 1.925 \\
\hline
\end{tabular}

\begin{tabular}{|c|c|c|c|}
\hline \multirow[t]{2}{*}{ Bl_11 } & Amphibalanus reticulatus & KU204256 & 1.794 \\
\hline & Amphibalanus reticulatus & KU204346 & 1.928 \\
\hline \multirow[t]{2}{*}{ B1_12 } & Amphibalanus reticulatus & KU204350 & 0.000 \\
\hline & Amphibalanus reticulatus & KU204370 & 0.173 \\
\hline \multirow{2}{*}{ B1_13 } & Amphibalanus reticulatus & KU204256 & 1.925 \\
\hline & Amphibalanus reticulatus & KU204370 & 2.104 \\
\hline \multirow[t]{2}{*}{ B1_15 } & Amphibalanus reticulatus & KU204370 & 0.173 \\
\hline & Amphibalanus sp. & MK995349 & 0.346 \\
\hline \multirow[t]{2}{*}{ Lb_01 } & Amphibalanus reticulatus & KU204256 & 2.104 \\
\hline & Amphibalanus reticulatus & KU204346 & 2.283 \\
\hline \multirow[t]{2}{*}{ Lb_02 } & Amphibalanus reticulatus & KU204370 & 0.173 \\
\hline & Amphibalanus reticulatus & KU204350 & 0.346 \\
\hline \multirow[t]{2}{*}{ Lb_03 } & Amphibalanus reticulatus & KU204320 & 0.173 \\
\hline & Amphibalanus reticulatus & KU204369 & 0.346 \\
\hline \multirow[t]{2}{*}{ Lb_04 } & Amphibalanus reticulatus & KU204346 & 0.519 \\
\hline & Amphibalanus reticulatus & KU204256 & 0.519 \\
\hline \multirow[t]{2}{*}{ Lb_05 } & Amphibalanus reticulatus & KU204346 & 0.519 \\
\hline & Amphibalanus reticulatus & KU204256 & 0.519 \\
\hline \multirow[t]{2}{*}{ Lb_06 } & Amphibalanus reticulatus & KU204370 & 0.000 \\
\hline & Amphibalanus reticulatus & KU204350 & 0.173 \\
\hline Lb_08 & Amphibalanus reticulatus & KU204370 & 0.000 \\
\hline & Amphibalanus reticulatus & KU204350 & 0.173 \\
\hline Lb_09 & Amphibalanus reticulatus & KU204350 & 0.173 \\
\hline & Amphibalanus reticulatus & KU204370 & 0.000 \\
\hline Lb_12 & Amphibalanus reticulatus & KU204370 & 0.000 \\
\hline & Amphibalanus reticulatus & KU204350 & 0.173 \\
\hline Lb_15 & Amphibalanus sp. & MK995352 & 0.000 \\
\hline & Amphibalanus sp. & MK995351 & 0.000 \\
\hline & Amphibalanus reticulatus & KU204350 & 0.173 \\
\hline Lp_01 & Amphibalanus reticulatus & KU204350 & 0.000 \\
\hline & Amphibalanus reticulatus & KU204370 & 0.173 \\
\hline Lp_02 & Amphibalanus reticulatus & KU204350 & 0.000 \\
\hline & Amphibalanus reticulatus & KU204370 & 0.173 \\
\hline Lp_04 & Amphibalanus reticulatus & KU204350 & 0.173 \\
\hline & Amphibalanus sp. & MK995352 & 0.000 \\
\hline Lp_06 & Amphibalanus reticulatus & KU204350 & 0.346 \\
\hline & Amphibalanus reticulatus & KU204370 & 0.519 \\
\hline Lp_07 & Amphibalanus reticulatus & KU204350 & 0.000 \\
\hline & Amphibalanus reticulatus & KU204370 & 0.173 \\
\hline Lp_09 & Amphibalanus reticulatus & KU204350 & 0.000 \\
\hline & Amphibalanus reticulatus & KU204370 & 0.173 \\
\hline Lp_10 & Amphibalanus reticulatus & KU204350 & 0.000 \\
\hline & Amphibalanus reticulatus & KU204370 & 0.173 \\
\hline Lp_12 & Amphibalanus sp. & MK995349 & 0.000 \\
\hline & Amphibalanus reticulatus & KU204350 & 0.000 \\
\hline Lp_15 & Amphibalanus reticulatus & KU204350 & 0.000 \\
\hline & Amphibalanus reticulatus & KU204370 & 0.173 \\
\hline Sr_01 & Amphibalanus reticulatus & KU204256 & 0.173 \\
\hline & Amphibalanus reticulatus & KU204346 & 0.519 \\
\hline Sr_02 & Amphibalanus reticulatus & KU204350 & 0.173 \\
\hline & Amphibalanus sp. & MK995352 & 2.470 \\
\hline Sr_03 & Amphibalanus reticulatus & KU204350 & 0.000 \\
\hline & Amphibalanus reticulatus & KU204261 & 0.000 \\
\hline $\mathrm{Sr} \_04$ & Amphibalanus reticulatus & KU204350 & 0.346 \\
\hline & Amphibalanus sp. & MK995352 & 0.173 \\
\hline $\mathrm{Sr}-05$ & Amphibalanus reticulatus & KU204350 & 0.000 \\
\hline & Amphibalanus reticulatus & KU204370 & 0.173 \\
\hline $\mathrm{Sr}+06$ & Amphibalanus reticulatus & KU204350 & 0.173 \\
\hline & Amphibalanus sp. & MK995352 & 0.000 \\
\hline Sr_07 & Amphibalanus sp. & MK995349 & 0.173 \\
\hline & Amphibalanus reticulatus & KU204350 & 0.173 \\
\hline Sr_09 & Amphibalanus reticulatus & KU204370 & 0.000 \\
\hline & Amphibalanus reticulatus & KU204350 & 0.173 \\
\hline $\mathrm{Sr} \_10$ & Amphibalanus reticulatus & KU204350 & 0.173 \\
\hline & Amphibalanus sp. & MK995352 & 0.000 \\
\hline $\mathrm{Sr} \_13$ & Amphibalanus reticulatus & KU204370 & 0.000 \\
\hline & Amphibalanus reticulatus & KU204350 & 0.173 \\
\hline $\mathrm{Sr}_{-} 15$ & Amphibalanus reticulatus & KU204350 & 0.173 \\
\hline & Amphibalanus sp. & MK995352 & 0.346 \\
\hline Jt_02 & Amphibalanus variegatus & MK995345 & 0.173 \\
\hline & Amphibalanus variegatus & MK995343 & 0.346 \\
\hline Jt_03 & Amphibalanus variegatus & MK995343 & 0.173 \\
\hline & Amphibalanus variegatus & MK995342 & 0.173 \\
\hline Ampl & anus reticulatus versus $A . v a$ & tus & $12.964-14.43$ \\
\hline
\end{tabular}




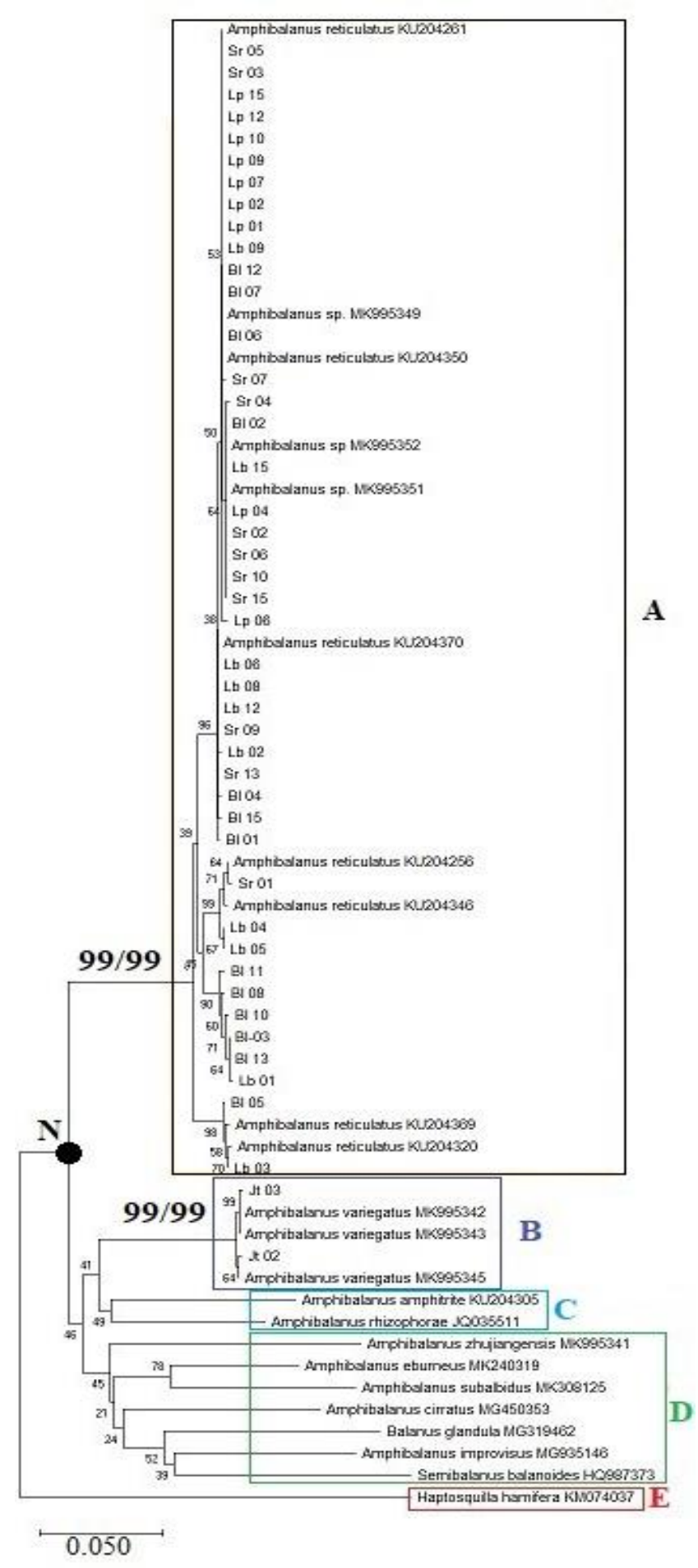

Figure 2. Phylogenetic tree showing the monophyly barnacles samples to their references species. Note: number indicate bootstrap values, clade A and clade B were supported by high $\mathrm{NJ}$ and ML bootstrap values
Low bootstraps values supported clade $\mathrm{C}, \mathrm{D}$, and $\mathrm{E}$ compared to clade A and B. It is reasonable because those three clades (C, D, and E) are composed of several different species, while clade $\mathrm{A}$ and $\mathrm{B}$ consist of individuals from single species, respectively. Nevertheless, since this study focuses on clade A and B, supported by high NJ and ML bootstrap values, it is reliable to state that the barnacle samples are phylogenetically identified as two different species.

According to Claridge et al. (1997), the phylogenetic species concept states that individuals' placement into single species is solely based on their monophyly. Therefore, it is compelling to determine that morphologically similar barnacle samples in this study belong to two different species. The samples from Lampung, Semarang, Bali, and Lombok belong to $A$. reticulatus, while samples from Jakarta belong to $A$. variegatus. Similar results were also reported by Nuryanto et al. (2017) and Kurniawaty et al. (2016), who also reported that monophyly between samples and reference species indicated that the samples belong to a single species.

Morphologically similar barnacle samples were genetically identified as A. reticulatus and A. variegatus. Species determinations were made based on nucleotide differences, nucleotide compositions, identity values, genetic distance, monophyly, and branch lengths in a phylogenetic tree. The taxonomic status of barnacle samples is listed in Table 5.

It is concluded that barnacle samples collected at five localities with similar morphologies have different molecular characteristics. Based on their molecular characteristics, the barnacle specimens used in this study could be separated into two genetically distinct groups. BLAST results, genetic distances, and monophyly analysis proved that barnacle samples belong to Amphibalanus reticulatus and $A$. variegatus.

\section{ACKNOWLEDGEMENTS}

We would like to thank the Directorate of Research and Public Services of The Ministry of Research, Technology, and Higher Education of The Republic of Indonesia, which provided funding to make this study possible through the Research Scheme of Penelitian Disertasi Doktor (PDD). We also wish to thank Faculty of Biology, Jenderal Soedirman University, Purwokerto, Indonesia, for the facilities that we utilized during the study. We also thank the people for their help during barnacle collection. Finally, we wish to thank the reviewers for their valuable suggestions and input, which have increased this manuscript's scientific value. 
Table 5. Taxonomic status of morphologically similar barnacles collected at five sampling sites in Indonesia

\begin{tabular}{|c|c|c|c|c|}
\hline Code & Order & Family & Genus & Species \\
\hline B1_01 & Sessilia & Balanidae & Amphibalanus & Amphibalanus reticulatus \\
\hline B1_02 & Sessilia & Balanidae & Amphibalanus & Amphibalanus reticulatus \\
\hline Bl_03 & Sessilia & Balanidae & Amphibalanus & Amphibalanus reticulatus \\
\hline Bl_04 & Sessilia & Balanidae & Amphibalanus & Amphibalanus reticulatus \\
\hline Bl_05 & Sessilia & Balanidae & Amphibalanus & Amphibalanus reticulatus \\
\hline B1_06 & Sessilia & Balanidae & Amphibalanus & Amphibalanus reticulatus \\
\hline B1_07 & Sessilia & Balanidae & Amphibalanus & Amphibalanus reticulatus \\
\hline B1_10 & Sessilia & Balanidae & Amphibalanus & Amphibalanus reticulatus \\
\hline B1_11 & Sessilia & Balanidae & Amphibalanus & Amphibalanus reticulatus \\
\hline B1_12 & Sessilia & Balanidae & Amphibalanus & Amphibalanus reticulatus \\
\hline B1_13 & Sessilia & Balanidae & Amphibalanus & Amphibalanus reticulatus \\
\hline B1_15 & Sessilia & Balanidae & Amphibalanus & Amphibalanus reticulatus \\
\hline Lb_01 & Sessilia & Balanidae & Amphibalanus & Amphibalanus reticulatus \\
\hline Lb_02 & Sessilia & Balanidae & Amphibalanus & Amphibalanus reticulatus \\
\hline Lb_03 & Sessilia & Balanidae & Amphibalanus & Amphibalanus reticulatus \\
\hline Lb_05 & Sessilia & Balanidae & Amphibalanus & Amphibalanus reticulatus \\
\hline Lb_06 & Sessilia & Balanidae & Amphibalanus & Amphibalanus reticulatus \\
\hline Lb_08 & Sessilia & Balanidae & Amphibalanus & Amphibalanus reticulatus \\
\hline Lb_09 & Sessilia & Balanidae & Amphibalanus & Amphibalanus reticulatus \\
\hline Lb_12 & Sessilia & Balanidae & Amphibalanus & Amphibalanus reticulatus \\
\hline Lb_15 & Sessilia & Balanidae & Amphibalanus & Amphibalanus reticulatus \\
\hline Lp_01 & Sessilia & Balanidae & Amphibalanus & Amphibalanus reticulatus \\
\hline Lp_02 & Sessilia & Balanidae & Amphibalanus & Amphibalanus reticulatus \\
\hline Lp_04 & Sessilia & Balanidae & Amphibalanus & Amphibalanus reticulatus \\
\hline Lp_06 & Sessilia & Balanidae & Amphibalanus & Amphibalanus reticulatus \\
\hline Lp_07 & Sessilia & Balanidae & Amphibalanus & Amphibalanus reticulatus \\
\hline Lp_09 & Sessilia & Balanidae & Amphibalanus & Amphibalanus reticulatus \\
\hline Lp_10 & Sessilia & Balanidae & Amphibalanus & Amphibalanus reticulatus \\
\hline Lp_12 & Sessilia & Balanidae & Amphibalanus & Amphibalanus reticulatus \\
\hline Lp_15 & Sessilia & Balanidae & Amphibalanus & Amphibalanus reticulatus \\
\hline Sr_01 & Sessilia & Balanidae & Amphibalanus & Amphibalanus reticulatus \\
\hline Sr_04 & Sessilia & Balanidae & Amphibalanus & Amphibalanus reticulatus \\
\hline Sr_05 & Sessilia & Balanidae & Amphibalanus & Amphibalanus reticulatus \\
\hline Sr_06 & Sessilia & Balanidae & Amphibalanus & Amphibalanus reticulatus \\
\hline Sr_07 & Sessilia & Balanidae & Amphibalanus & Amphibalanus reticulatus \\
\hline Sr_09 & Sessilia & Balanidae & Amphibalanus & Amphibalanus reticulatus \\
\hline $\mathrm{Sr} \_10$ & Sessilia & Balanidae & Amphibalanus & Amphibalanus reticulatus \\
\hline $\mathrm{Sr} \_13$ & Sessilia & Balanidae & Amphibalanus & Amphibalanus reticulatus \\
\hline $\mathrm{Sr} \_15$ & Sessilia & Balanidae & Amphibalanus & Amphibalanus reticulatus \\
\hline Jt_02 & Secoili & Balanidae & Amphibalanus & Amphibalanus variegatus \\
\hline Jt_03 & Sessilia & Balanidae & Amphibalanus & Amphibalanus variegatus \\
\hline
\end{tabular}

\section{REFERENCES}

Afreixo V, Bastos CAC, Pinho AJ, Garcia SP, Ferreira PJSG. 2009. Genome analysis with inter-nucleotide distances. Bioinformatics 25 (223): 3064-3070.

Aguilar A, Maeda-Martinez AM, Murugan G, Obregon-Barboza H, Rogers DC, McClintock K, Krumm JL. 2017. High intraspecific genetic divergence in the versatile fairy shrimp Branchinecta lindahli with a comment on cryptic species in the genus Branchinecta (Crustacea: Anostraca). Hydrobiol 801: 59-69. DOI: 10.1007/s10750017-3283-3

Bekker EI, Karabanov DP, Galimov YR, Kotov AA. 2016. DNA barcoding reveals high cryptic diversity in the North Eurasian Moina species (Crustacea: Cladocera). PLoS ONE 11 (8): e0161737. DOI: 10.1371/journal.pone.0161737.

Bhagawati D, Winarni ET, Nuryanto A. 2020. Molecular barcoding reveal the existence of mole crabs emerita emeritus in North Coast of Central Java. Biosaintifika 12 (1): 104-110.

Bilgin R, Utkan MA, Kalkan E, Karhan SU, Bekbolet M. 2015. DNA barcoding of twelve shrimp (Crustacea: Decapoda) from Turkish sea reveals cryptic diversity. Mediterr Mar Sci 16 (1): 36-45. DOI: $10.12681 / \mathrm{mms} .548$

Bucklin A, Hopcroft RR, Kosobokova KN, Nigro LM, Ortman BD, Jennings RM, Sweetmann CJ. 2010. DNA barcoding of Arctic Ocean holozooplankton for species identification and recognition. Deep-Sea Research II 57: 40-48.

Camacho AI, Dorda BA, Rey I. 2011. Identifying cryptic speciation across groundwater populations: First COI sequences of Bathynellidae (Crustacea, Syncarida). Graellsia 67 (1): 7-12. DOI: 10.3989/graellsia.2011.v67.031.

Candek K, Kuntner M. 2015. DNA barcoding gap: Reliable species identification over morphological and geographical scales. Mol Ecol Resour 15 (2): 268-277. DOI: 10.1111/1755-0998.12304

Carlton JT, Newman WA, Pitombo FB. 2011. Barnacle invasions: introduced, cryptogenic, and range expanding Cirripedia of North and South America. In: Galil BS, Clark PF, Carlton JT (eds.). In the Wrong Place - Alien Marine Crustaceans: Distribution, Biology and Impacts. Invading Nature-Springer Series in Invasion Ecology 6: 159. DOI 10.1007/978-94-007-0591-3_5. 
Chen HN, Tsang LM, Chong VC, Chan BK. 2014. Worldwide genetic differentiation in the common fouling barnacle, Amphibalanus amphitrite. Biofouling 30 (9): 1067-1078.

Claridge MF, Dawah HA, Wilson MR. 1997. Species: The Units of Biodiversity. Chapman and Hall, London.

da Silva JM, Creer S, dos Santos A, Costa AC, Cunha MR, Costa FO, Carvalho GR. 2011. Systematic and evolutionary insights derived from mtDNA COI barcode diversity in the Decapoda (Crustacea: Malacostraca). PLoS ONE 6 (5): e19449. DOI: 10.1371/journal.pone.0019449.

Elvyra R, Solihin DD, Afandi R, Junior MZ, Suhendra M. 2020. Molecular characteristics and phylogenetic relationships of silurid catfish (Kryptopterus, Ompok, and Phalacronatus) from the Kampar River, Indonesia, based on the cytochrome $\mathrm{b}$ gene. Biodiversitas 21 (8): 3539-3546. DOI: 10.13057/biodiv/d210816.

Excoffier L, Lischer HEL. 2010. Arlequin Suite Ver 3.5: A new series of programs to perform population genetics analyses under Linux and Windows. Mol Ecol Resour 10 (3): 564-567. DOI: 10.1111/j.17550998.2010.02847.x

Fertl D, Newman WA. 2018. Barnacles. In: Encyclopedia of Marine Mammals. 3rd ed. Academic Press, Cambridge, UK

Folmer O, Black M, Lutz R, Vrijenhoek R. 1994. DNA Primers for amplification of mitochondrial cytochrome $\mathrm{c}$ oxidase subunit i from metazoan invertebrates. Mol Mar Biol Biotechnol 3 (5): 294-299.

Frankham, R. 2003. Genetics and conservation. C.R. Biologies 326: 22 29

Hall TA. 2005. BioEdit: A user-friendly biological sequence alignmen editor and analysis program for Windows 95/98/NT. Nucleic Acids Symp Ser 41: 95-98. DOI: 10.14601/Phytopathol_Mediterr14998 u 1.29

Havermans C, Nagy ZT, Sonet G, De Broyer C, Martin P. 2011. DNA barcoding reveals new insights into the diversity of Antarctic species of Orchomene sensu lato (Crustacea: Amphipoda: Lysianassoidea). Deep-Sea Research II (58): 230-241.

Henry DP, McLaughlin PA. 1975. The barnacles of the Balanus amphitrite complex (Cirripedia, Thoracica). Zoologische Verhandelingen 141 (1): 1-254

Horikoshi A, Okamoto K. 2005. The first finding of the introduced barnacle Amphibalanus variegatus (Darwin) in Tokyo Bay. Sessile Organisms 22 (2): 47-50.

Hubert N, Meyer CP, Bruggeman HJ, Guerin F, Komeno RJL, Espiau B, Caussee R, Wiliams JT, Planes S. 2012. Cryptic diversity in IndoPacific coral reef fishes revealed by DNA barcoding provides new support to the center of overlap hypothesis. PloS One 7 (3): e28987. DOI: 10.1371 /journal.pone.0028987.

Jeffery NW, Elias-Guttierrez M, Adamowicz SJ. 2011. Species diversity and phylogeographical affinities of the Branchiopoda (Crustacea) of Churchill, Manitoba, Canada. PLoS One 6 (5): e18364. DOI: 10.1371/journal.pone.0018364.

Jones DS. 2012 Australian barnacles (Cirripedia: Thoracica), distribution and biogeographical affinities. Integrative and comparative biology, 52 (3): 366-387.

Jones DS, Hosie AM. 2016. A checklist of the barnacles (Cirripedia: Thoracica) of Singapore and neighbouring waters. Raffles Bull Zool 34: 241-311.

Karanovic I. 2015. Barcoding of ancient lake Ostracods (Crustacea) reveals cryptic speciation with extremely low distances. PLoS One 10 (3): e0121133. DOI: 10.1371/journal.pone.0121133.

Ko HL, Wang YT, Chiu TS, Lee MA, Leu MY, Chang KZ, Chen WY, Shao KT. 2013. Evaluating the accuracy of morphological identification of larval fishes by applying DNA barcoding. PLoS ONE 8 (1): 253451. DOI: 10.1371/journal.pone.0053451.

Kumar S, Stecher G, Li M, Knyaz C, Tamura K. 2018. MEGA X: Molecular evolutionary genetics analysis across computing platforms. Mol Biol Evol 35 (6): 1547-1549. DOI: 10.1093/molbev/msy096.

Kurniawaty N, Hidayat P, Rauf A. 2016. Characterization of three Species of thrips on banyan, nutmeg, and marine seruni plants based on COI gene. Biosaintifika 8 (2): 185-192.

Kusbiyanto, Bhagawati D, Nuryanto A. 2020. DNA barcoding of crustacean larvae in Segara Anakan, Cilacap, Central Java, Indonesia using cytochrome c oxidase gene. Biodiversitas 21 (10): 4878-4887. DOI: $10.13057 /$ biodiv/d211054.

Lin X, Stur E, Ekrem T. 2015. Exploring genetic divergence in a species rich insect genus using 2790 DNA barcodes. PLoS One 10 (9): e0138993. DOI: 10.1371/journal.pone.0138993.
Malakar AK, Lakra WS, Goswami M, Mishra RM. 2013. Genetic differentiation of Ompok bimaculatus (Teleostei: Siluridae) population based on mtDNA cytochrome $b$ gene. Mitochondrial DNA 24 (2): 145-150. DOI: 10.3109/19401736.2012.731400.

Maruzzo D, Aldred N, Clare AS, Hoeg JT. 2012. Metamorphosis in the cirripede crustacean Balanus amphitrite. PLoS One 7 (5): e37408. DOI: 10.1371/journal.pone.0037408.

Newman WA, Ross A. 1976. Revision of the balanomorph barnacles; including a catalog of the species. Mem San Diego Soc Nat Hist 9: 1108.

Nuryanto A, Pramono H, Sastranegara MH. 2017. Molecular identification of fish larvae from East Plawangan of Segara Anakan, Cilacap, Central Java, Indonesia. Biosaintifika 9 (1): 33-40. DOI: 10.15294/biosaintifika.v9i1.9191.

Nuryanto A, Amalia G, Khairani D, Pramono H, Bhagawati D. 2018. Molecular characterization four giant gourami strains from Java dan $\begin{array}{lllll}\text { Sumatra. } & \text { Biodiversitas } 19 & \text { (2): 528-539. }\end{array}$ 10.13057/biodiv/d190228

Nuryanto A, Komalawati N, Sugiharto. 2019. Genetic diversity assessment of Hemibagrus nemurus from rivers in Java Island, Indonesia using COI gene. Biodiversitas 20 (9): 2707-2717. DOI: 10.13057/biodiv/d200936.

Palecanda S, Feller KD, Porter ML. 2020. Using larval barcoding to estimate stomatopod species richness at Lizard Island, Australia for conservation monitoring. Sci Rep 10: 10990. DOI: 10.1038/s41598020-67696-x.

Palero F, Genis-Armero R, Hall MR, Clark PF. 2016. DNA barcoding the phyllosoma of Scyllarides squammosus (H. Milne Edwards, 1837) (Decapoda: Achelata: Scyllaridae). Zootaxa 4139 (4): 481 - 498. DOI: 10.11646/zootaxa.4139.4.2.

Pereira LHG, Hanner R, Foresti F, Oliveira C. 2013. Can DNA barcoding accurately discriminate megadiverse Neotropical freshwater fish fauna?. BMC Genet 14: 20. DOI: 10.1186/1471-2156-14-20.

Pérez-Losada M, Høeg JT, Crandall KA. 2004. Unraveling the evolutionary radiation of the thoracican barnacles using molecular and morphological evidence: A comparison of several divergence time estimation approaches. Syst Biol 53 (2): 244-264. DOI: 10.1080/10635150490423458

Pitombo FB. 2004. Phylogenetic analysis of the Balanidae (Cirripedia, Balanomorpha). Zoologica Scripta 33 (3): 261-276.

Pitriana P, Valente L, von Rintelen R, Jones DS, Prabowo RE, von Rintelen K. 2020. An annotated checklist and integrative biodiversity discovery of barnacles (Crustacea, Cirripedia) from the Moluccas, East Indonesia. ZooKeys 945: 17-83.

Pochai A, Kingtong S, Sukparangsi W, Khachonpisitsak S. 2017. The diversity of acorn barnacles (Cirripedia, Balanomorpha) across Thailand's coasts: The Andaman Sea and the Gulf of Thailand. Zoosystematics Evol 93: 13-34.

Power AM, Klepal W, Zheden V, Jonker J, McEvilly P, von Byern J. 2010. Mechanisms of adhesion in adult barnacles. In: von Byern J, Grunwald I. (eds.) Biological Adhesive Systems. Springer, Vienna.

Puspasari IA. 2001. Phylogeny of the Balanus amphitrite Complex (Cirripedia, Balanidae). [PhD Thesis]. Chiba University, Chiba.

Ratnasingham S. 2016. BOLDSYSTEMS. Available from: http://www.boldsystems.org/ (accessed 20 October 20)

Ratnasingham S, Hebert PDN. 2007. The barcode of life data system (http://www.barcodinglife.org). Molec Ecol Notes 7: 355-364.

Raupach MJ, Radulovici AE. 2015. Looking back on a decade barcoding crustaceans. Zookeys 539: 53-81. DOI: 10.3897/zookeys.539.6530

Riehl T, Brenke N, Brix S, Driskell A, Kaiser S, Brandt A. 2014. Field and laboratory methods for DNA studies on deep-sea isopod crustaceans. Polish Polar Res 35 (22): 203-224.

Shahdadi A, Sari A, Naderloo R. 2014. A checklist of the barnacles (Crustacea: Cirripedia: Thoracica) of the Persian Gulf and Gulf of Oman with nine new records. Zootaxa 3784 (3): 201-223. DOI: 10.11646/zootaxa.3784.3.1

Tang RWK, Yau C, Ng W-C. 2010. Identification of stomatopod larvae (Crustacea: Stomatopoda) from Hong Kong waters using DNA barcodes. Mol Ecol Res 10 (3): 439-448. DOI: 10.1111/j.17550998.2009.02794.x.

Thirumaraiselvi R, Das S, Ramanadevi V, Thangaraj M. 2015. MtDNA barcode identification of fisnfish larvae from Vellar Estuary, Tamilnadu, India. Notulae Scientia Biologicae 7 (1): 16-19.

Thompson JG, Higgins DG, Gibson TJ. 1994. CLUSTAL W: Improving the sensitivity of progressive multiple sequence alignments through sequence weighting, position-specific gap penalties and weight matrix 
choice. Nucleic Acids Res 22 (22): 4673-4680. DOI: $10.1093 / \mathrm{nar} / 22.22 .4673$.

von der Heyden S, Berger M, Toonen RJ, van Herwerden L, Juinio-Menez MA, Ravago-Gotanco R, Fauvelot C, Bernardi G. 2014. The application of genetics to marine management and consrvation: Examples from the Indo-Pacific. Bull Mar Sci 90 (1): 123-158. DOI: $10.5343 / \mathrm{bms} .2012 .1079$.
Walsh PS, Metzger DA, Higushi R. 2013. Chelex 100 as a medium for simple extraction of DNA for PCR-based typing from forensic material. Biotechniques 54 (3): 134-139.

Weis M, Macher JN, Seefeldt MA, Leese F. 2014. Molecular evidence for further overlooked species within the Gammarus fossarum complex (Crustacea: Amphipoda). Hydrobiology 721 (1): 165-184. DOI: $10.1007 / \mathrm{s} 10750-013-1658-7$. 